\title{
Review of Recent Research on AlCoCrFeNi High-Entropy Alloy
}

\author{
Marzena Tokarewicz * (D) and Małgorzata Grądzka-Dahlke (D) \\ Department of Materials and Production Engineering, Faculty of Mechanical Engineering, \\ Bialystok University of Technology, ul. Wiejska 45 C, 15-351 Białystok, Poland; m.dahlke@pb.edu.pl \\ * Correspondence: m.tokarewicz@doktoranci.pb.edu; Tel.: +48-571-439-100
}

check for updates

Citation: Tokarewicz, M.;

Grądzka-Dahlke, M. Review of Recent Research on $\mathrm{AlCoCrFeNi}$ High-Entropy Alloy. Metals 2021, 11, 1302. https://doi.org/10.3390/ met11081302

Academic Editor: Sergey V. Zherebtsov

Received: 7 July 2021

Accepted: 13 August 2021

Published: 17 August 2021

Publisher's Note: MDPI stays neutral with regard to jurisdictional claims in published maps and institutional affiliations.

Copyright: (c) 2021 by the authors. Licensee MDPI, Basel, Switzerland. This article is an open access article distributed under the terms and conditions of the Creative Commons Attribution (CC BY) license (https:// creativecommons.org/licenses/by/ $4.0 /)$.

\begin{abstract}
High-entropy alloys (HEAs) have gained significant interest in recent years because of their outstanding properties. The AlCoCrFeNi alloy is one of the most studied HEAs. The effect of the manufacturing methods and heat treatment on the properties of the high-entropy $\mathrm{AlCoCrFeNi}$ alloy is under intense scrutiny. The effect of varying component content on properties of the alloy is frequently analysed. Aluminium is most popular due to its impact on alloy microstructure and occurrence of phases. Research is also conducted on the influence of alloying additives, such as boron and titanium, on the properties of the AlCoCrFeNi alloy. High-entropy alloys also have excellent mechanical properties at high temperatures. Excellent structural and functional properties make them suitable for application in the most demanding conditions. The research conducted on HEAs still provides a lot of new and valuable information on the properties and structures of these alloys. This article summarizes the most important information about HEAs, specifically the AlCoCrFeNi alloy.
\end{abstract}

Keywords: $\mathrm{HEA} ; \mathrm{Al}_{\mathrm{x}} \mathrm{CoCrFeNi}$; manufacturing methods; annealing; mechanical properties

\section{The History of High-Entropy Alloys}

The design of traditional alloys is based on mixing one or two main components e.g., iron, titanium, aluminium, and adding small amounts of other elements to improve the properties by controlling the microstructure of the resulting alloy. This alloying strategy has been used consistently for hundreds of years. The traditional design of new alloys is limited by the number of possible compositions [1]. The rapid development of technology creates many challenges and limitations in traditional applications, for example, in constructions used in outer space. High Entropy Alloys (HEA) are a new generation of alloys, made by combining several elements in equal amounts. Depending on the used elements, these alloys offer high corrosion resistance, high yield stress, or high hardness, and many other useful properties. HEA were discovered quite recently-in the previous decade [2].

In the late $18^{\text {th }}$ century, German scientist and metallurgist Franz Karl Achard conducted research on alloys composed of 5-7 components in equal amounts. He was probably the first scientist that undertook the study of this type of alloy, which is why he is considered one of the precursors of HEA research. In 1788, Achard published a book entitled "Recherches sur les Proprietes des Alliages Metallique". In his book, he published the results of research on more than 900 different combinations of alloys obtained from the metals known at the time: iron, copper, tin, lead, zinc, bismuth, antimony, arsenic, silver, cobalt, and platinum. Achard carried out many experiments on the alloys, including measurements of density, hardness, strength, and plasticity. He observed that the properties of the resulting materials differed significantly from those of conventional alloys. The book presented only the results of tests without any detailed analysis, which made it unappreciated by other metallurgists all over the world [3].

In the late 20th century, Brian Cantor and his partners at the University of Oxford in the United Kingdom created alloys by mixing many different elements together. The investigated alloys consisted of varying numbers of elements in equiatomic amounts. The alloys were formed by induction melting. Melt quenching rapid solidification experiments 
were conducted on some samples. According to Professor Greer's principle of confusion, alloys prepared with such a large number of elements in equiatomic amounts have a high entropy of mixing, which should result in the formation of amorphous alloys. Professor Cantor's research results were unexpected and contrary to the principle of confusion. The alloys formed from 20 and 16 components were found to be multiphase and brittle. A simple single fcc structure was noticed to form in the five-component $\mathrm{Fe}_{20} \mathrm{Cr}_{20} \mathrm{Mn}_{20} \mathrm{Ni}_{20} \mathrm{Co}_{20}$ alloy. The study was extended to more components by adding other elements e.g., $\mathrm{Nb}, \mathrm{V}$, Ti, Ge. A dendritic microstructure was observed forming in the alloys. Professor Cantor's research results were extremely interesting because the number of phases in these alloys was always less than the number described by the Gibbs' Phase Rule [4,5].

Another scientist working on multi-component alloys at the same time as Brian Cantor was Jien-Wei Yeh. According to him, high mixing entropy might have reduced the number of phases and improved the mixing of components [6]. The professor and his students analysed over 40 alloys that were prepared through arc melting. They examined properties in the as-cast and annealed states, such as microstructure, hardness, and corrosion resistance. The alloy compositions consisted of commonly used elements e.g., titanium, vanadium, iron, chromium, nickel, cobalt, copper, molybdenum, zirconium, aluminium and palladium. Three percent boron was also added to some compositions. All the alloys exhibited high hardness levels in the range of 590-890 HV, depending on the present elements. Alloys with more elements were harder but with nine and more a decrease in hardness was noticed. A small addition of boron caused an increase in hardness. Between 2001 and 2003, Professor Yeh led nine other research projects. Five of them related to checking deformation behaviour, annealing, and wear resistance. Another two investigated thin films of high-entropy alloys obtained by magnetron sputtering and the last two were related to HEA elements in the form of thermal coatings. In the following years, the researcher published a wide variety of articles on high-entropic alloys and supervised dozens of master's theses and doctoral dissertations [7].

HEA alloys have caused a significant movement in the field of materials science due to their great potential as functional and structural materials [8]. The phenomenon of high-entropy alloys is caused by several main factors. HEA have very good mechanical properties, such as high hardness $[9,10]$, as well as the ability to maintain their strength at high temperatures [11], which is extremely important in the aerospace industry. The conducted experiments showed that particular HEAs have excellent oxidation resistance [12], wear resistance [13], and corrosion resistance [14]. These alloys are still not completely researched, so there is a perspective of discovering materials with unprecedented properties, which may result in innovative products and processes.

\section{The Definition of High-Entropy Alloys}

There are several alternative names for high-entropy alloys in the literature, e.g., multiple principal elements alloys (MPEAs) [15], complex concentrated alloys (CCAs) [16], complex multicomponent alloys (CMAs) [17], and compositionally complex alloys (CCAs) [18]. There is no clear definition of high entropy alloys in the literature, which causes some controversy and confusion. This is due to the fact that they were discovered relatively recently and have not been fully studied. With publication of new articles, new concepts and considerations come to light. Usually two definitions are identified, depending on the number of components or entropy value [19].

The most popular definition was proposed by Professor Yeh in 2004 [7], stating that HEAs contain from five to thirteen major elements. In the case of alloys with a smaller number of components, the mixing entropy in most alloy systems will not be high enough to counterbalance the enthalpy of mixing and ensure the formation of solid solution phases. On the other hand, a number of elements higher than 13 will not provide significant benefits. The concentration of each component of the alloy should vary between 5 and 35 at $\%[20,21]$. Therefore, alloys do not have to be equimolar, which significantly increases 
the possibility of obtaining appropriate properties. Alloying additives are also allowed in concentrations of less than $5 \%$ to improve the properties of the material [22].

An alternative definition is based on the entropy value. Entropy is a thermodynamic property that characterizes a static measure of the possible configurations of the distribution of atoms in a crystal lattice. It can be described as molecular disorder, or molecular randomness. Entropy increases as a system becomes more disordered and the positions of the molecules become less predictable [23]. Boltzmann's thermodynamic statistics principle defines the relationship between entropy and randomness of a system [24]:

$$
\Delta \mathrm{S}_{\mathrm{conf}}=\mathrm{R} \ln \mathrm{w},
$$

where $\mathrm{R}$ is the universal constant gas, $\mathrm{w}$ is the number of available microscopic states.

The total entropy of mixing depends on configurational entropy, translational entropy, rotational entropy, vibration entropy, magnetic entropy, electronic entropy, and nuclear entropy. Most studies only consider configurational entropy for calculating mixing entropy, because it is the dominant factor [25]. Depending on the configuration entropy, alloys are divided into three groups. In high-entropy alloys, the following relation occurs:

$$
\Delta \mathrm{S}_{\mathrm{c}} \geq 1.5 \mathrm{R},
$$

Depending on the value of S, medium-entropy alloys (MEA) and low-entropy alloys (LEA) can also be distinguished. The configuration entropy limits are as follows [26,27]:

$$
\begin{gathered}
\text { for MEA: } 1.0 \mathrm{R} \leq \Delta \mathrm{S}_{\mathrm{C}} \leq 1.5 \mathrm{R}, \\
\text { for LEA: } \Delta \mathrm{S}_{\mathrm{C}} \leq 1.0 \mathrm{R} .
\end{gathered}
$$

The configurational entropy assigned to high-entropy alloys is high enough to overcome the enthalpies of formation of intermetallic phases and form stabile solid solutions [28].

The provided HEA definition related to entropy value suggests that alloys have a constant configurational entropy value, but temperature significantly affects the alloy's entropy. These issues were solved by assuming that an alloy is "liquid solution and hightemperature solid solution states where the thermal energy is sufficiently high to cause different elements to have random positions in the structure." [29]. Using this assumption allows the alloy to be characterized by the maximum possible entropy it can achieve. It has also been pointed out in the literature that the Boltzmann equation allows estimating the configurational entropy from the alloy composition, but requires the atoms to occupy random positions in the lattice. This rarely occurs in metallic solutions, however, as they are generally not ideal [30].

\section{The Four "Core Effects"}

Professor Yeh formulated four "core effects" that appear in high-entropy alloys that arise from the specific structure that contains different atoms, which significantly affects the properties of materials. They are called high-entropy, lattice distortion, sluggish diffusion, and cocktail effects [29]. Due to their occurrence in high-entropy alloys, the principles of physical metallurgy are different from those in classical alloys, affecting the mechanical, physical and chemical properties, thermodynamics, structure, and microstructure of the alloy [31].

\subsection{High-Entropy Effect}

As mentioned earlier, entropy in high-entropy alloys mainly relates to configurational entropy $[7,25]$. High entropy results in lowering of the free energy of solid solution phases and enhances their formation, especially at higher temperatures. The increased mutual 
solubility between components results in a significant reduction of the phases present in HEAs [32]. According to Gibbs' phase rule:

$$
G=H-T * S,
$$

where $G$ is Gibbs free energy, $H$ is enthalpy, $T$ is temperature, and $S$ is entropy; phases in alloys with higher entropy have lower Gibbs free energy [33]. However, the effect of high entropy does not guarantee the formation of simple solid solutions in HEAs. Other significant determinants are the mixing enthalpy, atomic radius difference, and valence electron concentration. The competition between entropy and enthalpy also determines the phase formation [34]. At high temperature, the solid solution phases become the stable phase in HEAs. The degree of order in high-entropy alloys decreases with temperature increase. Hence, alloys containing ordered phases in the cast state may turn into random solid solutions at high temperature. However, when the enthalpy is high enough to overcome the entropy effect, such an intermetallic compound will still be stable [32]. When entropy overcomes enthalpy, then instead of complex metallic compounds, HEAs form more simple and common crystal structures such as bcc, fcc, hcp [35].

Some research articles suggest that there is not enough evidence that configurational entropy contributes to the solid solution stabilization and that it has a higher influence than in conventional alloys (e.g., high concentration alloys). Many alloys turn out to be unstable, despite high configurational entropy [28].

\subsection{Sluggish Diffusion Effect}

The slow atom diffusion effect refers to the fact that diffusion in high-entropy alloys is slower than in conventional alloys. Due to this phenomenon, HEAs have exceptional high-temperature strength [36], great high-temperature structural stability [37], and a tendency to form nanostructures [38]. In HEAs, the atoms surrounding each lattice site in the solid solution phases have a much greater diversity than in conventional alloys. This is because HEAs do not have a solvent component that dominates the composition of the solid solution phases and because they are composed of a minimum of five elements. Each site is surrounded by different atoms and also has a different bond configuration, which results in a different lattice potential energy (LPE) [39]. According to the literature, larger fluctuation of LPE results in slower diffusion and higher activation energy in HEAs. Sites with low LPE can hinder the diffusion of atoms, leading to a slow diffusion effect [40].

This hypothesis has been criticized by some researchers because depending on the comparison method, diffusion is higher or lower than in simpler alloys. Diffusion is compared using normalized homologous temperatures $\mathrm{T}_{\mathrm{m}} / \mathrm{T}\left(\mathrm{T}_{\mathrm{m}}\right.$ - melting point, $\mathrm{T}$ - test temperature) [41], alloys or using $1 / \mathrm{T}$. When the comparison is normalized by $\mathrm{T}_{\mathrm{m}}$, diffusion is slower, whereas otherwise, diffusion appears to be faster than in components and simpler alloys. According to some researchers, in high-entropy alloys, the slow diffusion may be overloaded by the lower melting temperature [42].

\subsection{Severe Lattice Distortion Effect}

In HEAs, the large number of alloy components resulting in a variety of atoms leads to greater lattice distortion than in conventional alloys. Every atom in HEAs is surrounded by other types of atoms having different sizes, resulting in higher lattice strain. Lattice distortion can be caused by different atomic sizes, but can also result from differences in crystal structure tendency and bonding energy among constituent elements [43]. The lattice distortion can reduce X-ray diffraction intensity, increase hardness, reduce electrical and thermal conductivity, and reduce the temperature dependence of these properties [42]. Figure 1 schematically illustrates the lattice distortion of a five-component high-entropy alloy. 


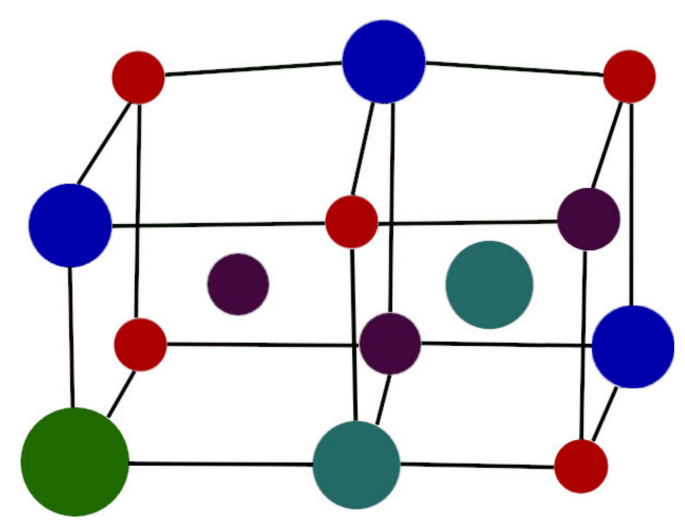

Figure 1. Schematic diagram of lattice distortion of five-component high-entropy alloy [21].

Recent articles raise questions about this effect. Researchers claim that the simultaneous occurrence of a severely strained lattice and a stable solid solution seems improbable. In addition, they claim that evidence for the occurrence of a lattice distortion greater than $5 \%$ of the lattice parameter is not clear. [28,30,42].

\subsection{Coctail Effect}

Ranganathan was the first to point out the cocktail effect that allows multi-component alloys to achieve unique properties [44]. This effect results in obtaining exceptional properties when several elements are mixed together and which cannot be achieved from a single element. The cocktail effect is that the properties of the alloy can be widely adjusted by changing the composition. The properties also depend on the interaction between all the elements [45].

\section{The AlCoCrFeNi High-Entropy Alloy}

The literature reports experiments on hundreds of different compositions of highentropy alloys. Not all obtained HEAs show similarly good properties. AlCoCrFeNi was one of the first investigated high-entropy alloys [7]. Table 1 compares the compressive properties of $\mathrm{AlCrFeCoNi}$ with other high-entropy alloys. Good mechanical properties $[46,47]$ have led to significant attention for this alloy.

Table 1. Room temperature mechanical properties of selected high-entropy alloys [48-51].

\begin{tabular}{cccc}
\hline Alloy & $\begin{array}{c}\text { Yield Strength } \\
{[\mathrm{MPa}]}\end{array}$ & $\begin{array}{c}\text { Compression } \\
\text { Strength } \\
{[\mathbf{M P a}]}\end{array}$ & $\begin{array}{c}\text { Plastic Strain } \\
{[\%]}\end{array}$ \\
\hline $\mathrm{AlCrFeCoNi}$ & 1250.96 & 2004.23 & 32.7 \\
\hline $\mathrm{CrFeCoNiCuTi}$ & 1272 & 1272 & 1.6 \\
\hline $\mathrm{CoCrCuFeNi}$ & 230 & 888 & 0.89 \\
\hline $\mathrm{AlCrMnFeCoNiCuTiV}$ & 1862 & 2431 & 0.95 \\
\hline $\mathrm{CrFeCoNiCuTi}$ & 1650 & 1428.7 & 6.6 \\
\hline $\mathrm{AlCrCuNi}$ & 700 & 1249 & 6.81 \\
\hline $\mathrm{VTaTiMoAl}$ & 1140.6 & & \\
\hline
\end{tabular}

The structure and mechanical properties of the AlCoCrFeNi alloy depend largely on the technology of alloy preparation, adjusted manufacturing parameters, and the type of heat treatment. Recently metallurgists are very eager to experiment, adding other elements to this composition such as $\mathrm{Ti}, \mathrm{Cu}$, and $\mathrm{Mo}$. It is also very common to change the percentage of particular elements in order to assess their influence on the structure and properties of the whole alloy. This is also present in the case of the AlCoCrFeNi alloy [52-54]; however, 
researchers are most willing to manipulate the aluminium content. The aim of modifying the composition and adjusting the manufacturing parameters is to obtain an alloy with the best possible properties.

\section{The $\mathrm{Al}_{\mathrm{x}} \mathrm{CoCrFeNi}$ High-Entropy Alloys}

Among all components of the alloy, aluminium shows the largest impact on the structure and properties; hence, the amount of information regarding $\mathrm{Al}_{\mathrm{x}} \mathrm{CoCrFeNi}$ alloy. As the aluminium content of the $\mathrm{Al}_{\mathrm{x}} \mathrm{CoCrFeNi}$ alloy increases, the fcc phase turns into the bcc phase $[55,56]$. For $x$ in the molar ratio, the structure changes as follows: fcc occurs when $\mathrm{x} \leq 0.4$, a mixed fcc and bcc phase appears between $0.5 \leq \mathrm{x} \leq 0.9$, a single bcc phase is present when $x \geq 0.9$ [57]. Through spinodal decomposition, the bcc phase consists of disordered bcc (A2) and ordered bcc (B2) [58]. Guo et al. indicate that the stability of the bcc or fcc in HEAs are associated with the concentration of valence electrons [59]. The change from fcc to bcc by increasing the Al content is also considered to occur due to lattice distortion. The alloys form a structure with lower atomic-packing efficiency, which is bcc due to the larger Al atomic size than the other major components [60]. Ogura et al. [61] explained the effect of $\mathrm{Al}$ content content on the phase transition. For this purpose, he used first principles electronic structure calculations. They claimed that the transformation from fcc to bcc with increasing Al content is mainly because of the high energy gain of the DO3 structure with Al addition. They observed that with increasing Al content, the total energy difference between fcc and bcc decreases. They pointed out that $\mathrm{Cr}$ and Fe stabilize the bcc structure, and $\mathrm{Ni}$ and $\mathrm{Co}$ are fcc stabilizers. Other studies also indicate that there is significant elemental segregation in the dendritic and interdendritic regions in the $\mathrm{Al}_{x} \mathrm{CrCoFeNi}$ alloy. The dendritic regions are enriched in $\mathrm{NiAl}$, while the interdendritic regions show an increased FeCr content [62]. For as-cast alloys, the microstructure also changes with the change in Al content [63]. The solidified microstructure changes from a columnar cellular when $\mathrm{x}$ in the molar ratio is up to 0.3 to a columnar dendritic structure when $0.4 \leq \mathrm{x} \leq 0.6$, then to equiaxed nondendritic grain when $0.7 \leq \mathrm{x} \leq 0.8$, next to equiaxed dendritic grains when $0.9 \leq \mathrm{x} \leq 1.5$ and finally to non-equiaxed dendritic structures when $1.8 \leq x \leq 2.0$ [57]. The Al content also affects other properties of the alloy. Increasing the aluminium content in the $\mathrm{Al}_{\mathrm{x}} \mathrm{CoCrFeNi}$ alloy increases its strength while decreasing its plasticity [64]. Figure 2 shows data from different sources regarding the increase in alloy hardness with Al content.

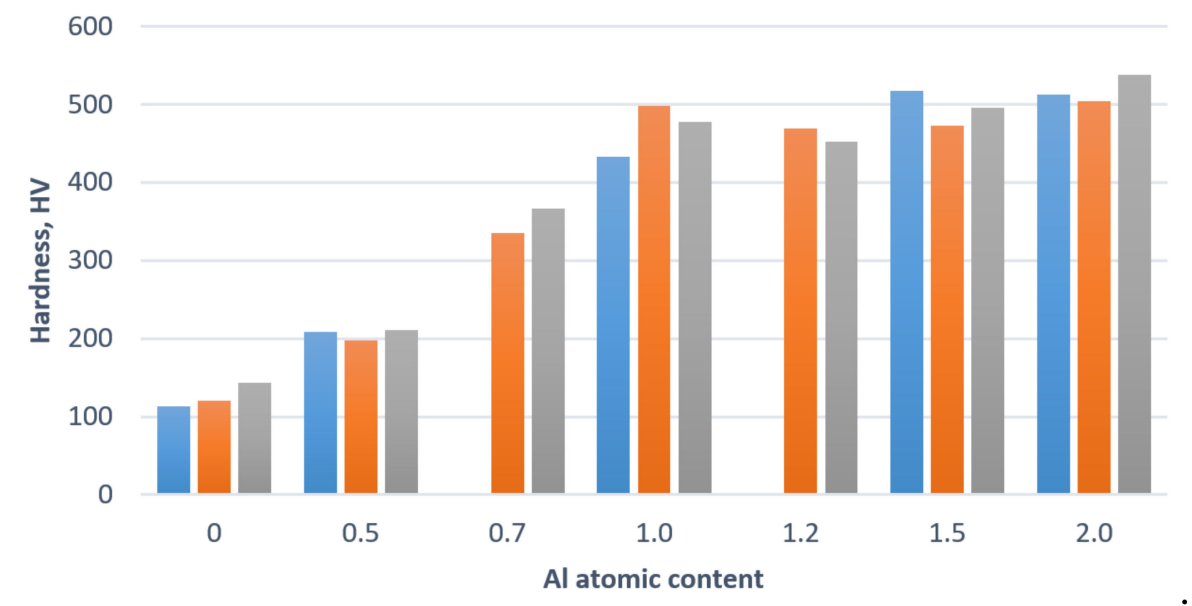

Figure 2. Effect of aluminium content on hardness of $\mathrm{Al}_{\mathrm{x}} \mathrm{CoCrFeNi}$ alloys (blue-based on [56], orange—based on [57], grey—based on authors' own unpublished research results).

Higher Al content improves the thermoelectric properties by increasing the maximum absolute value of the Seebeck coefficient and a simultaneous decrease in electrical conductivity. The ratio between electrical conductivity and lattice thermal conductivity 
decreases with increasing $\mathrm{Al}$ content [65]. Joseph et al. [66] investigated the sliding wear behavior of the $\mathrm{Al}_{x} \mathrm{CoCrFeNi}$ alloy from room temperature to temperature $900{ }^{\circ} \mathrm{C}$. The $\mathrm{Al}_{0.3} \mathrm{CoCrFeNi}$ alloy showed the highest wear rate at room temperature due to its soft fcc structure. The AlCoCrFeNi alloy showed the best wear resistance at all temperatures tested, at room temperature due to its high hardness, while at elevated temperatures due to the precipitation of the sigma phase. All HEAs showed significantly higher wear resistance than AISI 304 at temperatures above $300^{\circ} \mathrm{C}$ and Inconel 718 at temperatures greater than $800{ }^{\circ} \mathrm{C}$. The study showed a positive effect of increasing $\mathrm{Al}$ content in $\mathrm{AlxCoCrFeNi}$ alloy on wear properties. The $\mathrm{Al}_{x} \mathrm{CoCrFeNi}$ alloy with a low aluminium content shows weak magnetic properties, while a high content makes the alloy ferromagnetic. This is due to the change in the crystal structure of the alloy from the fcc phase to the bcc phase [67]. Studies indicate that as the $\mathrm{Al}$ content in $\mathrm{Al}_{x} \mathrm{CoCrFeNi}$ alloy increases, the corrosion resistance decreases due to the porosity and inferior nature of the $\mathrm{Al}$ protection oxide film in these alloys [68].

\section{Alloying Additives for the AlCoCrFeNi Alloy}

A number of studies have been conducted to examine the effect of alloying additives on the properties of the $\mathrm{AlCoCrFeNi}$ alloy. Ma et al. [69] investigated the effect of niobium addition on the $\mathrm{AlCoCrFeNb} \times \mathrm{Ni}$ alloy produced by arc melting. With the addition of $\mathrm{Nb}$, the single bcc phase transformed into the bcc phase and the Laves phase of $(\mathrm{CoCr}) \mathrm{Nb}$ type with a hexagonal close-packed (hcp) crystal lattice. The addition of $\mathrm{Nb}$ was pointed out as a cause of reduction in the dendrite size because of the $\mathrm{Nb}$ segregation in the interdendritic regions. With increasing $\mathrm{Nb}$ content, an increase in yield strength, hardness, and coercive forces was observed. On the other hand, a decrease in ductility, saturation magnetisations, and residual magnetisations was also noted. Based on the results obtained by the authors, selected properties are shown in Figure 3.

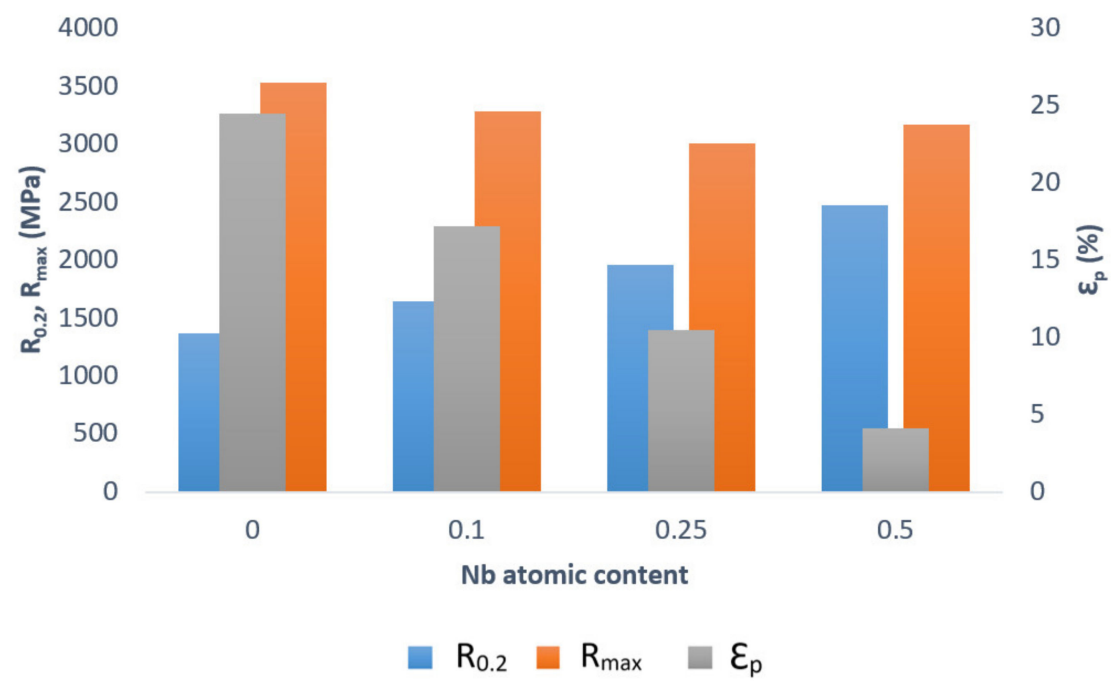

Figure 3. Effect of niobium content on the mechanical properties of the $\mathrm{AlCoCrFeNb} \times \mathrm{Ni}$ alloys (based on [69]).

Zhou et al. [10] conducted research on the AlCoCrFeNi alloy with the addition of titanium or cooper in various temperatures, to reveal the influence rules of chemical activity of adding element on the microstructure evolution of the AlCoCrFeNi system. The AlCoCrFeNiTi alloy mainly had bcc structures, but in the alloy with $\mathrm{Ti}_{1.5}$, a bcc phase with a Laves phase occurred. The lattice phase deformation in the $\mathrm{AlCoCrFeNiTi}_{0.5}$ alloy deepened with increasing temperature to $800{ }^{\circ} \mathrm{C}$, which resulted in an increase of the material hardness, then decreased as the temperature further increased. The AlCoCrFeNiTi ${ }_{0.5}$ alloy showed the best mechanical properties, Young's modulus was $177.7 \mathrm{GPa}$, yield stress 
was 2.26 GPa, fracture strength was 3.14 GPa, and plastic strain was $23.3 \%$. On the other hand, in the case of the AlCoCrFeNiCu alloy, structural transformations-formation of metastable $\mathrm{Cu}$-rich FCC1 phases and $\sigma$-phase precipitations-occurring during heating resulted in lower hardness.

Dong et al. [70] studied the effect of vanadium addition on the properties of an $\mathrm{AlCoCrFeNi}$ alloy. The $\mathrm{V}$ content in the studied alloys ranged from 0 to 1 in molar ratio. The vanadium addition had no influence on the crystal lattice structure, but increasing the vanadium content increased the lattice constants. The authors pointed out that vanadium has the second-largest atomic radius of all the alloy components, which causes lattice distortion and thus increases the lattice constant. The study showed that vanadium addition reduces elemental segregation. The highest yield strength and hardness was observed in the $\mathrm{AlCoCrFeNiV}$ alloy (1726.5 $\mathrm{MPa}, 648.8 \mathrm{HV}$, respectively), whereas the highest plastic strain and compressive strength was noted in the $\mathrm{AlCoCrFeNiV}_{0.2}$ alloy $(26.8 \%, 3297.8 \mathrm{MPa}$, respectively). Chen et al. [71] studied the effect of adding zirconium to an AlCoCrFeNi alloy. Increase in the amount of $\mathrm{Zr}$ was observed to lead to the appearance of new phase besides bcc, identified in the paper as the Laves phase identified as $\mathrm{ZrX}_{2}(\mathrm{X}=\mathrm{Co}$ or Ni). In the AlCoCrFeNiZr $r_{x}$ alloy, ordering (Laves phase) and spinodal decomposition were observed. The addition of $\mathrm{Zr}$ above 0.1 in molar ratio was noticed to lead to decrease in plastic strain and compressive strength, whereas yield strength increases with increasing $\mathrm{Zr}$ amount. The AlCrCoNiFeZr $\mathrm{A}_{0.008}$ alloy had a yield strength of $1560 \mathrm{MPa}$, a fracture strength of $3513 \mathrm{MPa}$, a plastic strain of $29.5 \%$, and these values were higher than in the alloy without $\mathrm{Zr}$ addition. The effect of boron addition in the $\mathrm{AlCoCrFeNi}$ alloy on its properties was also studied. The $\mathrm{Al}_{\mathrm{x}} \mathrm{CoCrFeB}_{0.2}$ alloy had the highest fracture strength, compressive ratio, and hardness $(2643.475 \mathrm{MPa}, 30.6 \%, 502.4 \mathrm{HV}$, respectively). It was observed that the addition of boron $\mathrm{x} \leq 0.2$ in molar ratio caused an improvement in the alloy properties, whereas a higher addition caused a deterioration. The authors indicated that this was caused by an increasing amount of FCC phase with a higher boron quantity [72].

\section{Manufacturing Methods}

The most widely used casting method for high-entropy alloys is arc melting [73], and vacuum induction melting (VIM) [74]. Tian et al. [75] compared the properties of AlCoCrFeNi alloy obtained through induction levitation melting and arc melting. The sample obtained by induction levitation melting had higher yield strength (1631 MPa) and microhardness $(519 \mathrm{HV})$ compared to the sample obtained by arc melting (1209 MPa and $493 \mathrm{HV}$ ). However, the alloy obtained by arc melting showed higher ductility. A technology that allows to obtain a very homogeneous structure in case of HEA is powder metallurgy with mechanical alloying and SPS (Spark Plasma Sintering) [76]. The results showed that the sintering temperature affects the microstructure of the resulting alloy and consequently the mechanical properties. As the sintering temperature increases, a tendency for the formation of $\mathrm{Ni}$-Al-poor fcc phase was observed as well as the transformation from $\mathrm{Cr}-\mathrm{Fe}$ rich bcc phase to $\mathrm{Cr}$-rich bcc phase within the $\mathrm{B} 2$ phase. The highest compressive strength $(2368 \mathrm{MPa})$ and compression ratio $(22.1 \%)$ were obtained for the alloy sintered at $1100{ }^{\circ} \mathrm{C}$, while the yield strength $(1626 \mathrm{MPa})$ for the specimen was obtained at $1250{ }^{\circ} \mathrm{C}$. Whereas according to other test results, the AlCoCrFeNi alloy also produced by SPS method at 1250 ${ }^{\circ} \mathrm{C}$ showed yield strength of $1262 \mathrm{MPa}$, compressive strength of $3228 \mathrm{MPa}$ and ultimate plasticity strain of $29.1 \%$ [77].

A research into the application of additive technologies for HEA manufacturing is being conducted [78,79]. Niu et al. [79] studied an AlCrCoFeNi alloy produced by selective laser melting (SLM). The paper indicates that the alloy can have a single bcc or dual bcc + fcc or A2 + B2 phase depending on the cooling rate. The maximum values of microhardness (853.23 HV) and Young's modulus (198.90 GPa) were obtained for samples with the highest volumetric energy density (VED) of $111.1 \mathrm{~J} / \mathrm{mm}^{3}$. The authors point to the high cooling rate and higher amount of $\mathrm{B} 2$ phase as reasons for the good properties. The study by Wang et al. [46] confirm the influence of cooling rates on the mechanical properties of the 
alloys. They increased the cooling rate of the specimens by reducing their diameters, which resulted in improved strength and ductility.

In conclusion, the $\mathrm{AlCrCoFeNi}$ alloy is very sensitive to the method of manufacturing. The parameters of the technological process have a crucial impact on the structure and, therefore, the properties of the material.

\section{Effect of Annealing on the Properties of the AlCoCrFeNi Alloy}

Application of additional heat treatment can also affect the structure and properties of the AlCoCrFeNi alloy. Research was also carried out on the effect of annealing on the properties and microstructure of the $\mathrm{AlCoCrFeNi}$ alloy. As mentioned earlier, the $\mathrm{AlCoCrFeNi}$ alloy exhibits a bcc phase consisting of A2 and B2. It has been observed that annealing at temperatures above $600{ }^{\circ} \mathrm{C}$ causes the formation of the fcc phase. The precipitated fcc consists of the $\mathrm{AlNi}_{3}$ phase, while the bcc consists of $\mathrm{FeCo}$. The formation of a sigma $\mathrm{Fe}_{0.5} \mathrm{Cr}_{0.5}$ phase, which is an intermetallic component, is also observed. Occurring fcc and sigma phase precipitates cause an increase in hardness [80]. Changes in the crystalline structure after annealing are confirmed by many test results [81]. Cheng et al. produced a coating from $\mathrm{AlCoCrFeNi}$ powders. The resulting raw powder had $\mathrm{A} 2$ and B2 phase, which agrees with the previously cited studies. The powder did not show any changes in microstructure after annealing at temperatures below $500{ }^{\circ} \mathrm{C}$. The results confirm that the formation of the fcc phase starts only at temperatures above $600{ }^{\circ} \mathrm{C}$. When the temperature reached $800^{\circ} \mathrm{C}$, the $\mathrm{Fe}-\mathrm{Cr}$ sigma phase precipitated. As the temperature gets closer to the melting point, the fcc phase becomes dominant. A decrease in the fcc phase was observed at $1200^{\circ} \mathrm{C}$. The researchers indicate that this is due to a remelting effect that leads to recrystallization of the bcc phase into coarse grains [82]. Sigma phase present in the $\mathrm{AlCoCrFeNi}$ alloy after annealing at $900{ }^{\circ} \mathrm{C}$ shows a hardness of $11.87 \mathrm{GPa}$. These studies also indicated that the fcc phase had a hardness of $7.88 \mathrm{GPa}$, while bcc had a hardness of $5.28 \mathrm{GPa}$. According to the researchers, the fcc phase showed higher hardness than bcc due to the effect of precipitation hardening [80].

\section{AlCoCrFeNi Coatings}

High-entropy alloys are also used for creating films and coatings on common metal substrates to improve their properties. Various technologies are used for this purpose, e.g., magnetron sputtering [83,84], laser cladding [85], and plasma spraying [86], among others. However, differences in chemistry, thermal expansion, and residual stresses of materials can cause cracking and separation of coatings [87]. Cui et. al. [88] decided to use intermediate layers to overcome the differences between materials with the formation of an $\mathrm{AlCoCrFeNi}$ coating on an AISI 304 stainless steel substrate. The researchers used the laser metal deposition (LMD) method. The $\mathrm{CoFe}_{2} \mathrm{Ni}$ intermediate layer resulted in an improvement in bonding and an absence of cracks. The measured Vickers hardness of the uncoated material was below $175 \mathrm{HV}$, the intermediate layer was $275 \mathrm{HV}$ and the HEA deposit was ca. $418 \mathrm{HV}$. The authors indicated that the reason for the hardness variations is due to differences in the phases present-AISI 304 has an FCC phase, $\mathrm{CoFe}_{2} \mathrm{Ni}$ a mixture of FCC and BCC phases, and AlCoCrFeNi a BCC phase. Kemény et al. [89] used an electrochemical deposition method to produce a coating on a copper substrate. The results confirm the increase in hardness after application of the HEA coating. Corrosion tests confirmed that the $\mathrm{AlCoCrFeNi}$ coating decreases the corrosion rate. A study comparing the corrosion resistance between $\mathrm{AlCoCrFeNi}$ coatings obtained by electrospark deposition and the as-cast $\mathrm{AlCoCrFeNi}$ revealed that the corrosion current of the coated sample is significantly lower. The authors of the investigation claimed that this is caused by the absence of a Cr-rich interdendritic phase and the precipitation of a second phase in the cast material [90]. Many other studies also show an improvement in material properties after the application of the $\mathrm{AlCoCrFeNi}$ coatings [91,92]. 


\section{Applications of the High-Entropy AlCoCrFeNi Alloy}

High-entropy alloys gain a lot of interest due to their outstanding properties. Wide possibilities of adjusting their properties by using various manufacturing methods and changing alloy composition make them suitable for many applications. The $\mathrm{AlCoCrFeNi}$ alloy exhibits good mechanical properties at high temperatures. The high heat resistance of the AlCoCrFeNi alloy means that it could be successfully used in high-temperature structural applications, for example, aerospace engine components [93]. As previously mentioned, high-entropy alloys can be used as coatings to protect the surfaces of machine components and parts because of their high hardness, wear resistance, heat resistance, corrosion resistance, or combinations of these properties [94]. High-entropy alloys based on ferromagnetic elements such as $\mathrm{Fe}, \mathrm{Co}$ and $\mathrm{Ni}$ are soft-magnetic. Traditional soft magnetic materials like Fe-Al have a high degree of structural order, which leads to poor deformability. Amorphous soft-magnetic materials are difficult to manufacture and their low recrystallization temperature limits their usability at high temperatures. HEAs have a flexible forming process, corrosion resistance, and soft magnetic properties. The excellent ductility of HEAs offers the possibility to prepare thin plates, which can effectively reduce eddy current losses in magnetic devices [95]. Li et al. produced fibres from $\mathrm{Al}_{0.3} \mathrm{CoCrFeNi}$ HEA with a diameter of $1-3.15 \mathrm{~mm}$. The $1 \mathrm{~mm}$ diameter fibre exhibited great tensile strength and ductility at $298 \mathrm{~K}$ [96]. Liao et al. fabricated an $\mathrm{Al}_{0.3} \mathrm{CoCrFeNi}_{\text {film through }}$ magnetron sputtering. Magnetron sputtering offers the possibility of fabricating small structure devices and micro instruments [97]. The high-entropy $\mathrm{AlCoCrFeNi} 2.1$ alloy can be used for ship propellers due to its corrosion resistance and good casting properties [98]. An electrochemical impedance spectroscopy study carried out by P. Socorro-Perdomo et. al. in a simulated human body environment showed that $\mathrm{Al}_{\mathrm{x}} \mathrm{CoCrFeNi}(\mathrm{x}=0.6,0.8$, and 1.0) alloys are suitable for use as medical instrument materials [99]. The amount of research on high-entropy alloys is growing constantly, but there is still much to be discovered. With new knowledge also comes more potential applications.

\section{Conclusions}

This paper is an attempt to systematise and summarise existing knowledge concerning high-entropy alloys, in particular the $\mathrm{AlCoCrFeNi}$ alloy. The AlCoCrFeNi alloy is one of the first produced high-entropy alloys. Many studies and experiments have been carried out to investigate its mechanical and functional properties. The conclusions of this review are as follows:

The aluminium content of the $\mathrm{Al}_{\mathrm{x}} \mathrm{CoCrFeNi}$ alloy significantly affects its microstructure, phases, and properties. With the addition of aluminium, the fcc phase in the alloy is transformed into a mixture of fcc and bcc phases and then into a single bcc phase. The change of phases in the alloy influences its mechanical properties. The change from the fcc phase to the bcc phase increases the hardness of the alloy and decreases its ductility. In addition, the magnetic properties of the alloy are improved with an increase in the amount of aluminium, but the corrosion resistance decreases.

High-entropy alloys are produced by powder metallurgy, casting, and additive manufacturing methods. The selected preparation method affects the properties of the highentropy alloy. The influence of the cooling rate on the properties of the $\mathrm{AlCoCrFeNi}$ alloy is also observed.

Research into the influence of heat treatment on the properties of the $\mathrm{AlCoCrFeNi}$ alloy was conducted. Phase changes in the alloy were observed above $600^{\circ} \mathrm{C}$. The sigma phase, which has the highest hardness, precipitates in the alloy at temperatures above $800{ }^{\circ} \mathrm{C}$.

The AlCoCrFeNi alloy has good heat resistance and excellent mechanical properties. It can be used to manufacture components working at high temperatures, e.g., aeroplane parts. High-entropy alloys are also used as coatings to protect the surfaces of machine parts. 
Funding: This research was funded by the program of the Minister of Science and Higher Education of Poland named "Regional Initiative of Excellence" in 2019-2022 project number 011/RID/2018/19 amount of financing 12,000,000 PLN".

Institutional Review Board Statement: Not applicate.

Informed Consent Statement: Not applicate.

Data Availability Statement: The date presented in this study are available on request from the corresponding author.

Conflicts of Interest: The authors declare no conflict of interest.

\section{References}

1. Kang, B.; Lee, J.; Ryu, H.J.; Hong, S.H. Ultra-High Strength WNbMoTaV High-Entropy Alloys with Fine Grain Structure Fabricated by Powder Metallurgical Process. Mater. Sci. Eng. A 2018, 712, 616-624. [CrossRef]

2. Raza, A.; Kang, B.; Lee, J.; Ryu, H.J.; Hong, S.H. Transition in Microstructural and Mechanical Behavior by Reduction of Sigma-Forming Element Content in a Novel High Entropy Alloy. Mater. Des. 2018, 145, 11-19. [CrossRef]

3. Murty, B.S.; Yeh, J.-W.; Ranganathan, S. A Brief History of Alloys and the Birth of High-Entropy Alloys. In High-Entropy Alloys; Butterworth-Heinemann: Oxford, UK, 2014; pp. 1-12.

4. Cantor, B.; Chang, I.T.H.; Knight, P.; Vincent, A.J.B. Microstructural Development in Equiatomic Multicomponent Alloys. Mater. Sci. Eng. A 2004, 375-377, 213-218. [CrossRef]

5. Zhang, Y. High-Entropy Materials: A Brief Introduction; Springer: Singapore, 2019; ISBN 9789811385254.

6. George, E.P.; Raabe, D.; Ritchie, R.O. High-Entropy Alloys. Nat. Rev. Mater. 2019, 4, 515-534. [CrossRef]

7. Yeh, J.-W.; Chen, S.-K.; Lin, S.-J.; Gan, J.-Y.; Chin, T.-S.; Shun, T.-T.; Tsau, C.-H.; Chang, S.-Y. Nanostructured High-Entropy Alloys with Multiple Principal Elements: Novel Alloy Design Concepts and Outcomes. Adv. Eng. Mater. 2004, 6, 299-303. [CrossRef]

8. Tsai, M.-H. Physical Properties of High Entropy Alloys. Entropy 2013, 15, 5338-5345. [CrossRef]

9. Zhu, J.M.; Fu, H.M.; Zhang, H.F.; Wang, A.M.; Li, H.; Hu, Z.Q. Synthesis and Properties of Multiprincipal Component AlCoCrFeNiSix Alloys. Mater. Sci. Eng. A 2010, 527, 7210-7214. [CrossRef]

10. Zhou, Y.J.; Zhang, Y.; Wang, Y.L.; Chen, G.L. Solid Solution Alloys of AlCoCrFeNiTix with Excellent Room-Temperature Mechanical Properties. Appl. Phys. Lett. 2007, 90, 181904. [CrossRef]

11. Hsu, C.Y.; Juan, C.C.; Wang, W.R.; Sheu, T.S.; Yeh, J.W.; Chen, S.K. On the Superior Hot Hardness and Softening Resistance of AlCoCrxFeMo0.5Ni High-Entropy Alloys. Mater. Sci. Eng. A 2011, 528, 3581-3588. [CrossRef]

12. Liu, C.; Wang, H.; Zhang, S.; Tang, H.; Zhang, A. Microstructure and oxidation behavior of new refractory high entropy alloys. J. Alloys Compd. 2014, 583, 162-169. [CrossRef]

13. Chuang, M.H.; Tsai, M.H.; Wang, W.R.; Lin, S.J.; Yeh, J.W. Microstructure and Wear Behavior of AlxCo 1.5CrFeNi1.5Tiy HighEntropy Alloys. Acta Mater. 2011, 59, 6308-6317. [CrossRef]

14. Lee, C.P.; Chen, Y.Y.; Hsu, C.Y.; Yeh, J.W.; Shih, H.C. The Effect of Boron on the Corrosion Resistance of the High Entropy Alloys $\mathrm{Al}_{0.5} \mathrm{CoCrCuFeNiB}_{\mathrm{x}}$. J. Electrochem. Soc. 2007, 154, C424. [CrossRef]

15. Yang, X.; Zhang, Y. Prediction of High-Entropy Stabilized Solid-Solution in Multi-Component Alloys. Mater. Chem. Phys. 2012, 132, 233-238. [CrossRef]

16. Borkar, T.; Gwalani, B.; Choudhuri, D.; Mikler, C.V.; Yannetta, C.J.; Chen, X.; Ramanujan, R.V.; Styles, M.J.; Gibson, M.A.; Banerjee, R. A Combinatorial Assessment of $\mathrm{Al}_{\mathrm{x}} \mathrm{CrCuFeNi}_{2}(0<\mathrm{x}<1.5)$ Complex Concentrated Alloys: Microstructure, Microhardness, and Magnetic Properties. Acta Mater. 2016, 116, 63-76. [CrossRef]

17. Ng, C.; Guo, S.; Luan, J.; Shi, S.; Liu, C.T. Entropy-Driven Phase Stability and Slow Diffusion Kinetics in an $\mathrm{Al}_{0.5} \mathrm{CoCrCuFeNi}$ High Entropy Alloy. Intermetallics 2012, 31, 165-172. [CrossRef]

18. Gao, M.C.; Yeh, J.-W.; Liaw, P.K.; Zhang, Y. High-Entropy Alloys: Fundamentals and Applications; Springer: Berlin/Heidelberg, Germany, 2016.

19. Zhang, W.; Liaw, P.K.; Zhang, Y. Science and Technology in High-Entropy Alloys. Sci. China Mater. 2018, 61, 2-22. [CrossRef]

20. Yeh, J.W.; Chen, Y.L.; Lin, S.J.; Chen, S.K. High-Entropy Alloys-A New Era of Exploitation. Mater. Sci. Forum 2007, 560, 1-9. [CrossRef]

21. Yin, X.; Xu, S. Properties and Preparation of High Entropy Alloys. In International Conference on Materials Applications and Engineering 2017 (ICMAE2017); EDP Sciences: Les Ulis, France, 2018; Volume 142.

22. Zhou, Y.; Zhang, Y.; Wang, Y.; Chen, G. Microstructure and Compressive Properties of Multicomponent $\mathrm{Al}_{\mathrm{x}}\left(\mathrm{TiVCrMnFeCoNiCu}_{100-\mathrm{x}}\right.$ High-Entropy Alloys. Mater. Sci. Eng. A 2007, 454-455, 260-265. [CrossRef]

23. Çengel, Y.A.; Boles, M.A. Thermodynamics: An Engineering Approach (SI Units). Available online: https://public.ebookcentral proquest.com/choice/ publicfullrecord.aspx? $\mathrm{p}=5115249$ (accessed on 13 August 2021).

24. Tien, C.L.; Lienhard, J.H. Statistical Thermodynamics; HRW Series in Mechanical Engineering; Taylor \& Francis: Melbourne, Australia, 1979; ISBN 978-0-89116-828-7.

25. Zhang, Y.; Xing, Q. High Entropy Alloys: Manufacturing Routes. In Reference Module in Materials Science and Materials Engineering; Elsevier: Amsterdam, The Netherlands, 2020; ISBN 978-0-12-803581-8. 
26. Miracle, D.; Miller, J.; Senkov, O.; Woodward, C.; Uchic, M.; Tiley, J. Exploration and Development of High Entropy Alloys for Structural Applications. Entropy 2014, 16, 494-525. [CrossRef]

27. Carroll, R.; Lee, C.; Tsai, C.W.; Yeh, J.W.; Antonaglia, J.; Brinkman, B.A.W.; Leblanc, M.; Xie, X.; Chen, S.; Liaw, P.K.; et al. Experiments and Model for Serration Statistics in Low-Entropy, Medium-Entropy, and High-Entropy Alloys. Sci. Rep. 2015, 5, 16997. [CrossRef]

28. Pickering, E.J.; Jones, N.G. High-Entropy Alloys: A Critical Assessment of Their Founding Principles and Future Prospects. Int. Mater. Rev. 2016, 61, 183-202. [CrossRef]

29. Yeh, J. Recent Progress in High-Entropy Alloys. Ann. Chim. Sci. Mat. 2006, 31, 633-648. [CrossRef]

30. Miracle, D.B.; Senkov, O.N. A Critical Review of High Entropy Alloys and Related Concepts. Acta Mater. 2017, $122,448-511$. [CrossRef]

31. Yeh, J.-W. Physical Metallurgy of High-Entropy Alloys. JOM 2015, 67, 2254-2261. [CrossRef]

32. Tsai, M.-H.; Yeh, J.-W. High-Entropy Alloys: A Critical Review. Mater. Res. Lett. 2014, 2, 107-123. [CrossRef]

33. Chen, J.; Zhou, X.; Wang, W.; Liu, B.; Lv, Y.; Yang, W.; Xu, D.; Liu, Y. A Review on Fundamental of High Entropy Alloys with Promising High-Temperature Properties. J. Alloys Compd. 2018, 760, 15-30. [CrossRef]

34. Guo, S.; Hu, Q.; Ng, C.; Liu, C.T. More than Entropy in High-Entropy Alloys: Forming Solid Solutions or Amorphous Phase. Intermetallics 2013, 41, 96-103. [CrossRef]

35. Chenzhong, Y.A.O.; Huixuan, M.A.; Yexiang, T. Electrochemical Preparation and Magnetic Study of Amorphous Nanostructural Nd-Fe-Co-Ni-Mn High Entropy Alloy Film. Chin. J. Appl. Chem. 2011, 28, 1189. [CrossRef]

36. Senkov, O.; Wilks, G.; Scott, J.; Miracle, D. Mechanical Properties of $\mathrm{Nb}_{25} \mathrm{Mo}_{25} \mathrm{Ta}_{25} \mathrm{~W}_{25}$ and $\mathrm{V}_{20} \mathrm{Nb}_{20} \mathrm{Mo}_{20} \mathrm{Ta}_{20} \mathrm{~W}_{20} \mathrm{Refractory}$ High Entropy Alloys. Intermetallics 2011, 19, 698-706. [CrossRef]

37. Tsai, M.-H.; Wang, C.-W.; Tsai, C.-W.; Shen, W.-J.; Yeh, J.-W.; Gan, J.-Y.; Wu, W.-W. Thermal Stability and Performance of NbSiTaTiZr High-Entropy Alloy Barrier for Copper Metallization. J. Electrochem. Soc. 2011, 158, H1161. [CrossRef]

38. Shun, T.-T.; Hung, C.-H.; Lee, C.-F. Formation of Ordered/Disordered Nanoparticles in FCC High Entropy Alloys. J. Alloys Compd. 2010, 493, 105-109. [CrossRef]

39. Tsai, K.-Y.; Tsai, M.-H.; Yeh, J.-W. Sluggish Diffusion in Co-Cr-Fe-Mn-Ni High-Entropy Alloys. Acta Mater 2013, 61, 4887-4897. [CrossRef]

40. Yeh, J.-W. Alloy Design Strategies and Future Trends in High-Entropy Alloys. JOM 2013, 65, 1759-1771. [CrossRef]

41. Vaidya, M.; Trubel, S.; Murty, B.; Wilde, G.; Divinski, S. Ni Tracer Diffusion in CoCrFeNi and CoCrFeMnNi High Entropy Alloys. J. Alloys Compd. 2016, 688, 994-1001. [CrossRef]

42. Miracle, D. High-Entropy Alloys: A Current Evaluation of Founding Ideas and Core Effects and Exploring "Nonlinear Alloys". JOM 2017, 69, 2130-2136. [CrossRef]

43. Zhang, Y.; Zhou, Y.; Hui, X.; Wang, M.; Chen, G. Minor Alloying Behavior in Bulk Metallic Glasses and High-Entropy Alloys. Sci. China Ser. G-Phys. Mech. Astron. 2008, 51, 427-437. [CrossRef]

44. Ranganathan, S. Alloyed Pleasures: Multimetallic Cocktails. Curr. Sci. 2003, 85, 1404-1406.

45. Zhang, Y.; Zuo, T.T.; Tang, Z.; Gao, M.C.; Dahmen, K.A.; Liaw, P.K.; Lu, Z.P. Microstructures and Properties of High-Entropy Alloys. Prog. Mater. Sci. 2014, 61,1-93. [CrossRef]

46. Wang, F.J.; Zhang, Y.; Chen, G.L.; Davies, H.A. Cooling Rate and Size Effect on the Microstructure and Mechanical Properties of AlCoCrFeNi High Entropy Alloy. J. Eng. Mater. Technol. 2009, 131. [CrossRef]

47. Chou, H.-P.; Chang, Y.-S.; Chen, S.-K.; Yeh, J.-W. Microstructure, Thermophysical and Electrical Properties in $\mathrm{Al}_{\mathrm{x}} \mathrm{CoCrFeNi}$ $(0 \leq \mathrm{x} \leq 2)$ High-Entropy Alloys. Mater. Sci. Eng. B 2009, 163, 184-189. [CrossRef]

48. Wang, X.F.; Zhang, Y.; Qiao, Y.; Chen, G.L. Novel Microstructure and Properties of Multicomponent CoCrCuFeNiTi $\mathrm{x}_{\mathrm{x}}$ Alloys. Intermetallics 2007, 15, 357-362. [CrossRef]

49. Wang, Y.P.; Li, B.S.; Ren, M.X.; Yang, C.; Fu, H.Z. Microstructure and Compressive Properties of AlCrFeCoNi High Entropy Alloy. Mater. Sci. Eng. A 2008, 491, 154-158. [CrossRef]

50. Wang, X.-R.; Wang, Z.-Q.; Lin, T.-S.; He, P. Microstructure, Thermodynamics and Compressive Properties of AlCrCuNiZr $x$ (x = 0.1) High-Entropy Alloys. Mater. Sci. Technol. 2016, 32, 1289-1295. [CrossRef]

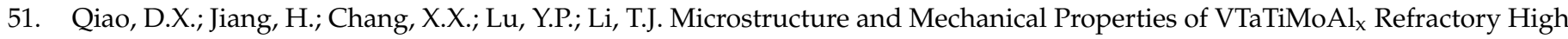
Entropy Alloys. Mater. Sci. Forum 2017, 898, 638-642. [CrossRef]

52. López Ríos, M.; Socorro Perdomo, P.P.; Voiculescu, I.; Geanta, V.; Crăciun, V.; Boerasu, I.; Mirza Rosca, J.C. Effects of Nickel Content on the Microstructure, Microhardness and Corrosion Behavior of High-Entropy AlCoCrFeNix Alloys. Sci. Rep. 2020, 10, 21119. [CrossRef] [PubMed]

53. Shun, T.-T.; Hung, W.-J. Effects of Cr Content on Microstructure and Mechanical Properties of AlCoCrxFeNi High-Entropy Alloy. Adv. Mater. Sci. Eng. 2018, 2018, 5826467. [CrossRef]

54. Guo, L.; Xiao, D.; Wu, W.; Ni, S.; Song, M. Effect of Fe on Microstructure, Phase Evolution and Mechanical Properties of (AlCoCrFeNi)100-XFex High Entropy Alloys Processed by Spark Plasma Sintering. Intermetallics 2018, 103, 1-11. [CrossRef]

55. Tong, C.-J.; Chen, Y.-L.; Yeh, J.-W.; Lin, S.-J.; Chen, S.-K.; Shun, T.-T.; Tsau, C.-H.; Chang, S.-Y. Microstructure Characterization of $\mathrm{Al}_{\mathrm{x}} \mathrm{CoCrCuFeNi}$ High-Entropy Alloy System with Multiprincipal Elements. Metall. Mater. Trans. A 2005, 36, 881-893. [CrossRef]

56. Kao, Y.-F.; Chen, T.-J.; Chen, S.-K.; Yeh, J.-W. Microstructure and Mechanical Property of As-Cast, -Homogenized, and -Deformed $\mathrm{Al}_{\mathrm{x}} \mathrm{CoCrFeNi}(0 \leq \mathrm{x} \leq 2)$ High-Entropy Alloys. J. Alloys Compd. 2009, 488, 57-64. [CrossRef] 
57. Wang, W.-R.; Wang, W.-L.; Wang, S.-C.; Tsai, Y.-C.; Lai, C.-H.; Yeh, J.-W. Effects of Al Addition on the Microstructure and Mechanical Property of $\mathrm{Al}_{\mathrm{x}} \mathrm{CoCrFeNi}$ High-Entropy Alloys. Intermetallics 2012, 26, 44-51. [CrossRef]

58. Praveen, S.; Kim, H.S. High-Entropy Alloys: Potential Candidates for High-Temperature Applications-An Overview. Adv. Eng. Mater. 2017, 20, 1700645. [CrossRef]

59. Guo, S.; Ng, C.; Lu, J.; Liu, C.T. Effect of Valence Electron Concentration on Stability of Fcc or Bcc Phase in High Entropy Alloys. J. Appl. Phys. 2011, 109, 103505. [CrossRef]

60. Wang, F.; Zhang, Y.; Chen, G. Atomic Packing Efficiency and Phase Transition in a High Entropy Alloy. J. Alloys Compd. 2009, 478, 321-324. [CrossRef]

61. Ogura, M.; Fukushima, T.; Zeller, R.; Dederichs, P.H. Structure of the High-Entropy Alloy $\mathrm{Al}_{x} \mathrm{CrFeCoNi:} \mathrm{Fcc} \mathrm{versus} \mathrm{Bcc.} \mathrm{J.} \mathrm{Alloys}$ Compd. 2017, 715, 454-459. [CrossRef]

62. Manzoni, A.; Daoud, H.; Völkl, R.; Glatzel, U.; Wanderka, N. Phase Separation in Equiatomic AlCoCrFeNi High-Entropy Alloy. Ultramicroscopy 2013, 132, 212-215. [CrossRef] [PubMed]

63. Geanta, V.; Voiculescu, I.; Milosan, I.; Istrate, B.; Mates, I.M. Chemical Composition Influence on Microhardness, Microstructure and Phase Morphology of AlxCrFeCoNi High Entropy Alloys. Rev. Chim. 2018, 69, 798-801. [CrossRef]

64. Joseph, J.; Jarvis, T.; Wu, X.; Stanford, N.; Hodgson, P.; Fabijanic, D.M. Comparative Study of the Microstructures and Mechanical Properties of Direct Laser Fabricated and Arc-Melted Al $\mathrm{C}$ CoCrFeNi High Entropy Alloys. Mater. Sci. Eng. A 2015, 633, 184-193. [CrossRef]

65. Shafeie, S.; Guo, S.; Hu, Q.; Fahlquist, H.; Erhart, P.; Palmqvist, A. High-Entropy Alloys as High-Temperature Thermoelectric Materials. J. Appl. Phys. 2015, 118, 184905. [CrossRef]

66. Joseph, J.; Haghdadi, N.; Shamlaye, K.; Hodgson, P.; Barnett, M.; Fabijanic, D. The Sliding Wear Behaviour of CoCrFeMnNi and $\mathrm{Al}_{\mathrm{x}} \mathrm{CoCrFeNi}$ High Entropy Alloys at Elevated Temperatures. Wear 2019, 428-429, 32-44. [CrossRef]

67. Kao, Y.-F.; Chen, S.-K.; Chen, T.-J.; Chu, P.-C.; Yeh, J.-W.; Lin, S.-J. Electrical, Magnetic, and Hall Properties of Al $\mathrm{Al}_{\mathrm{x}} \mathrm{CoCF}$ (Ni High-Entropy Alloys. J. Alloys Compd. 2011, 509, 1607-1614. [CrossRef]

68. Kao, Y.-F.; Lee, T.-D.; Chen, S.-K.; Chang, Y.-S. Electrochemical Passive Properties of $\mathrm{Al}_{\mathrm{X}} \mathrm{CoCrFeNi}(\mathrm{X}=0,0.25,0.50,1.00) \mathrm{Alloys}$ in Sulfuric Acids. Corro. Sci. 2010, 52, 1026-1034. [CrossRef]

69. Ma, S.G.; Zhang, Y. Effect of Nb Addition on the Microstructure and Properties of AlCoCrFeNi High-Entropy Alloy. Mater. Sci. Eng. A 2012, 532, 480-486. [CrossRef]

70. Dong, Y.; Zhou, K.; Lu, Y.; Gao, X.; Wang, T.; Li, T. Effect of Vanadium Addition on the Microstructure and Properties of AlCoCrFeNi High Entropy Alloy. Mater. Des. 2014, 57, 67-72. [CrossRef]

71. Chen, J.; Niu, P.; Liu, Y.; Lu, Y.; Wang, X.; Peng, Y.; Liu, J. Effect of Zr Content on Microstructure and Mechanical Properties of AlCoCrFeNi High Entropy Alloy. Mater. Des. 2016, 94, 39-44. [CrossRef]

72. Chen, Q.; Lu, Y.; Dong, Y.; Wang, T.; Li, T. Effect of Minor B Addition on Microstructure and Properties of AlCoCrFeNi Multi-Compenent Alloy. Trans. Nonferrous Met. Soc. China 2015, 25, 2958-2964. [CrossRef]

73. Cheng, B.; Zhang, F.; Lou, H.; Chen, X.; Liaw, P.K.; Yan, J.; Zeng, Z.; Ding, Y.; Zeng, Q. Pressure-Induced Phase Transition in the AlCoCrFeNi High-Entropy Alloy. Scr. Mater. 2019, 161, 88-92. [CrossRef]

74. Cao, T.; Shang, J.; Zhao, J.; Cheng, C.; Wang, R.; Wang, H. The Influence of Al Elements on the Structure and the Creep Behavior of $\mathrm{Al}_{\mathrm{x}} \mathrm{CoCrFeNi}$ High Entropy Alloys. Mater. Lett. 2016, 164, 344-347. [CrossRef]

75. Tian, Q.; Zhang, G.; Yin, K.; Wang, W.; Cheng, W.; Wang, Y. The Strengthening Effects of Relatively Lightweight AlCoCrFeNi High Entropy Alloy. Mater. Charact. 2019, 151, 302-309. [CrossRef]

76. Zhou, P.F.; Xiao, D.H.; Wu, Z.; Song, M. Microstructure and Mechanical Properties of AlCoCrFeNi High Entropy Alloys Produced by Spark Plasma Sintering. Mater. Res. Express 2019, 6, 0865e7. [CrossRef]

77. Zhang, A.; Han, J.; Meng, J.; Su, B.; Li, P. Rapid Preparation of AlCoCrFeNi High Entropy Alloy by Spark Plasma Sintering from Elemental Powder Mixture. Mater. Lett. 2016, 181, 82-85. [CrossRef]

78. Al-shataif, Y.A.; Sivasankaran, S.; Al-Mufadi, F.A.; Alaboodi, A.S.; Ammar, H.R. Manufacturing Methods, Microstructural and Mechanical Properties Evolutions of High-Entropy Alloys: A Review. Met. Mater. Int. 2020, 26, 1099-1133. [CrossRef]

79. Niu, P.; Li, R.; Yuan, T.; Zhu, S.; Chen, C.; Wang, M.; Huang, L. Microstructures and Properties of an Equimolar AlCoCrFeNi High Entropy Alloy Printed by Selective Laser Melting. Intermetallics 2018, 104, 24-32. [CrossRef]

80. Liang, J.-T.; Cheng, K.-C.; Chen, S.-H. Effect of Heat Treatment on the Phase Evolution and Mechanical Properties of Atomized AlCoCrFeNi High-Entropy Alloy Powders. J. Alloys Compd. 2019, 803, 484-490. [CrossRef]

81. Munitz, A.; Salhov, S.; Hayun, S.; Frage, N. Heat Treatment Impacts the Micro-Structure and Mechanical Properties of AlCoCrFeNi High Entropy Alloy. J. Alloys Compd. 2016, 683, 221-230. [CrossRef]

82. Cheng, K.-C.; Chen, J.-H.; Stadler, S.; Chen, S.-H. Properties of Atomized AlCoCrFeNi High-Entropy Alloy Powders and Their Phase-Adjustable Coatings Prepared via Plasma Spray Process. Appl. Surf. Sci. 2019, 478, 478-486. [CrossRef]

83. An, Z.; Jia, H.; Wu, Y.; Rack, P.D.; Patchen, A.D.; Liu, Y.; Ren, Y.; Li, N.; Liaw, P.K. Solid-Solution CrCoCuFeNi High-Entropy Alloy Thin Films Synthesized by Sputter Deposition. Mater. Res. Lett. 2015, 3, 203-209. [CrossRef]

84. Kim, Y.S.; Park, H.J.; Mun, S.C.; Jumaev, E.; Hong, S.H.; Song, G.; Kim, J.T.; Park, Y.K.; Kim, K.S.; Jeong, S.I.; et al. Investigation of Structure and Mechanical Properties of TiZrHfNiCuCo High Entropy Alloy Thin Films Synthesized by Magnetron Sputtering. J. Alloys Compd. 2019, 797, 834-841. [CrossRef] 
85. Yue, T.M.; Xie, H.; Lin, X.; Yang, H.O.; Meng, G.H. Solidification Behaviour in Laser Cladding of AlCoCrCuFeNi High-Entropy Alloy on Magnesium Substrates. J. Alloys Compd. 2014, 587, 588-593. [CrossRef]

86. Wang, W.; Qi, W.; Xie, L.; Yang, X.; Li, J.; Zhang, Y. Microstructure and Corrosion Behavior of (CoCrFeNi)95Nb5 High-Entropy Alloy Coating Fabricated by Plasma Spraying. Materials 2019, 12, 694. [CrossRef] [PubMed]

87. Sistla, H.R.; Newkirk, J.; Liou, F. Effect of Al/Ni Ratio, Heat Treatment on Phase Transformations and Microstructure of AlxFeCoCrNi2x $(x=0.3,1)$ High Entropy Alloys. Mater. Des. 2015, 81, 113-121. [CrossRef]

88. Cui, W.; Karnati, S.; Zhang, X.; Burns, E.; Liou, F. Fabrication of AlCoCrFeNi High-Entropy Alloy Coating on an AISI 304 Substrate via a CoFe2Ni Intermediate Layer. Entropy 2019, 21, 2. [CrossRef]

89. Kemény, D.M.; Miskolcziné Pálfi, N.; Fazakas, É. Examination of Microstructure and Corrosion Properties of Novel AlCoCrFeNi Multicomponent Alloy. Mater. Today Proc. 2021, 45, 4250-4253. [CrossRef]

90. Li, Q.H.; Yue, T.M.; Guo, Z.N.; Lin, X. Microstructure and Corrosion Properties of AlCoCrFeNi High Entropy Alloy Coatings Deposited on AISI 1045 Steel by the Electrospark Process. Metall. Mater. Trans. A 2013, 44, 1767-1778. [CrossRef]

91. Meghwal, A.; Anupam, A.; Luzin, V.; Schulz, C.; Hall, C.; Murty, B.S.; Kottada, R.S.; Berndt, C.C.; Ang, A.S.M. Multiscale Mechanical Performance and Corrosion Behaviour of Plasma Sprayed AlCoCrFeNi High-Entropy Alloy Coatings. J. Alloys Compd. 2021, 854, 157140. [CrossRef]

92. Li, W.; Liu, P.; Liaw, P.K. Microstructures and Properties of High-Entropy Alloy Films and Coatings: A Review. Mater. Res. Lett. 2018, 6, 199-229. [CrossRef]

93. Lim, K.R.; Lee, K.S.; Lee, J.S.; Kim, J.Y.; Chang, H.J.; Na, Y.S. Dual-Phase High-Entropy Alloys for High-Temperature Structural Applications. J. Alloys Compd. 2017, 728, 1235-1238. [CrossRef]

94. Chikumba, S.; Rao, V.V. High Entropy Alloys: Development and Applications. In Proceedings of the 7th Int. Conf. Latest Trends Eng. Technology, Irene, South Africa, 26-27 November 2015; pp. 1-5.

95. Yan, X.; Zhang, Y. Functional Properties and Promising Applications of High Entropy Alloys. Scr. Mater. 2020, 187, $188-193$. [CrossRef]

96. Li, D.; Li, C.; Feng, T.; Zhang, Y.; Sha, G.; Lewandowski, J.J.; Liaw, P.K.; Zhang, Y. High-Entropy Al ${ }_{0.3} \mathrm{CoCrFeNi}_{\mathrm{Alloy}}$ Fibers with High Tensile Strength and Ductility at Ambient and Cryogenic Temperatures. Acta Mater. 2017, 123, 285-294. [CrossRef]

97. Liao, W.-B.; Zhang, H.; Liu, Z.-Y.; Li, P.-F.; Huang, J.-J.; Yu, C.-Y.; Lu, Y. High Strength and Deformation Mechanisms of $\mathrm{Al}_{0.3} \mathrm{CoCrFeNi}$ High-Entropy Alloy Thin Films Fabricated by Magnetron Sputtering. Entropy 2019, 21, 146. [CrossRef]

98. Yeh, J.-W.; Lin, S.-J. Breakthrough Applications of High-Entropy Materials. J. Mater. Res. 2018, 33, 3129-3137. [CrossRef]

99. Socorro-Perdomo, P.P.; Florido-Suárez, N.R.; Voiculescu, I.; Mirza-Rosca, J.C. Comparative EIS Study of AlxCoCrFeNi Alloys in Ringer's Solution for Medical Instruments. Metals 2021, 11, 928. [CrossRef] 